\title{
Cardio-thoracic ratio in Negroes in Southern Africa
}

\author{
AleXANDeR R. P. WALKeR* \\ D.Sc. \\ M. Wadvalla \\ B. D. RICHARDSON
M.Sc. \\ B. F. WALKER \\ South African Medical Research Council Human Biochemistry Research Unit, \\ South African Institute for Medical Research, Johannesburg, South Africa
}

\begin{abstract}
Summary
Negro groups in West, Central and Southern Africa, also in Jamaica, have mean cardio-thoracic ratios significantly greater than those in corresponding agesex groups of Caucasians.

To throw more light on the situation, studies on young and elderly Negroes have been made in certain groups in Southern Africa, also on local Caucasian groups. Only slight differences in ratio were found between local Negro groups, and Caucasian groups in South Africa, also in Wales and Tecumseh (U.S.A.). Yet ratios in Negro males from Malawi and Mozambique, resident in South Africa, were significantly greater than values in local Negroes. High ratios are not therefore invariable for Negroes. The difference observed relates to heart, not thoracic diameter. Since the phenomenon, which concerns heart position, is apparent in the young, almost certainly it is of ethnic origin. Investigations on cardiomegaly in African populations must take this factor into reckoning. Its presence or absence locally may readily be assessed by determining ratios in relatively small numbers of young people of both sexes.
\end{abstract}

\section{Introduction}

In West, Central, and Southern Africa, it has been reported that cardio-thoracic ratios are greater in Negroes than in Caucasians (Pellegrino, Favre \& Doerin, 1955; Brown, 1953; Trowell, 1960; Gelfand, 1952; Oosthuizen, 1958). In Jamaica, studies of rural and urban Negro communities revealed that the mean cardio-thoracic ratio was greater compared with data on corresponding sex and age groups studied in Wales (Ashcroft \& Miall, 1969; Cochrane, Miall \& Clark, 1956). Differences increased with age (period 35-64 years), were more pronounced in females than in males, and in rural than in urban communities. It was concluded that the discrepancies could not be explained by differences in the prevalence of cardio-vascular disorders including hyper-

\footnotetext{
* Dr A. R. P. Walker, M.R.C. Human Biochemistry Research Unit, South African Institute for Medical Research, P.O. Box 1038, Johannesburg, South Africa.
}

tension, nor by differences in weight nor physical activity. It was considered that there may be an ethnic difference, possibly in the position of the heart within the chest, or in the thoracic diameter. These workers suggested that it would be of value to make a comparison of cardio-thoracic measurements of Africans and Caucasians living in the same environment, particularly in younger persons, among whom the influence of cardio-vascular disorders would be minimal.

Requisite measurements have therefore been made on groups of Southern African Negroes in rural and urban areas, also on groups of local Caucasians Initially, data were obtained from series of X-ras plates made by us for investigations on the bearing of calcium intake on bone dimensions in different populations (Walker, Walker \& Richardson, 1970). Later, data were readily secured from groups of people who had been X-rayed for health purposes. The investigation was undertaken (1) to seek to answer the questions raised by Ashcroft \& Miall (1969), (2) because of our interest in differences, ethnic and environmental, and their sequelae, in the populations of Southern Africa, and (3) because of current interest in the prevalence and aetiology of African cardiomyopathies, of which cardiomegaly is a feature (Trowell, 1960).

\section{Material and methods}

\section{Subjects}

In an investigation such as the present, measurements can be made on age and sex groups who are random groups without respect to disease, such as were examined in the Jamaican study. Alternatively, subjects may be divided into two groups, as was done at Tecumseh, U.S.A. (Oberman et al., 1967), namely: (1) 'normal' healthy persons, and (2) 'abnormal' persons. The latter suffered from one of the following: (i) coronary heart disease, (ii) rheumatic heart disease, (iii) congenital heart disease, (iv) hypertension, i.e. the upper twentieth percentile of Tecumseh population or greater than $160 / 90 \mathrm{mmHg}$, 
(v) hypertensive heart disease, and (vi) congestive heart failure. It is important to note that even at Tecumseh, in the 20-29-year period, the 'abnormal' group constituted $35 \%$ of subjects, the proportion rising to $60 \%$ in the $60-69$-year period.

It was decided to follow the selection procedure and age groupings used in the Jamaican study. Briefly, the groups investigated were-rural Negroes of the Tswana tribe, also groups of young mine labourers from Malawi and Mozambique currently working in South Africa; urban Negroes, mainly Zulus; and Caucasian groups.

\section{Negroes: rural}

(1) Plates were obtained from George Stegmann Mission Hospital (altitude $4000 \mathrm{ft}$ ), Saulspoort, 140 miles north west of Johannesburg. Fifty or more chest X-ray plates of Negro (Tswana) nurses, also of mine workers, of 18-20 years, all in outward good health, were examined. Further, from persons of both sexes at least fifty X-ray plates from each sex group (25-34, 35-44, and 55-64 years) were studied; subjects mainly were negative contacts of tuberculosis patients.

(2) Another Tswana group, living in a village near Rustenburg ( 80 miles west of Johannesburg), comprised subjects of 55-64 years. They numbered nineteen males and twenty-nine females and constituted 95.0 and $96.7 \%$, respectively, of total subjects of that age living there. They were examined principally for bone dimension studies at the Hospital at Rustenburg.

(3) Plates were examined of groups of young 'foreign' migrant mine workers of 18-20, 25-34, 35-44, and 55-64 years, employed at Rustenburg Platinum Mine. There were approximately fifty in each age group of Negroes from Malawi (1000 miles north of Johannesburg), and of Shangaan Negroes from Mozambique (400-500 miles east of Johannesburg). X-ray plates, available from routine examinations, were randomly selected; the radiography had been carried out at the Hospital attached to the mine. Workers enjoyed everyday good health.

\section{Negroes: urban}

(1) Male and female groups comprised persons examined at Mofolo Clinic, Soweto, Johannesburg (altitude $5500 \mathrm{ft}$ ). They were mainly persons who were negative contacts of tuberculosis patients. They were of mixed tribal origin, although predominantly Zulu. Age groups were 18-20, 25-34, 35-44, and 55-64 years. Each sex-age group included at least fifty persons. They were consecutive cases attending the clinic, and were reasonably representative of mixed town Negroes.

(2) A further group, of 55-64 years, included forty-five males and fifty-two females, and consti- tuted 95.7 and $96.3 \%$, respectively, of Negroes of that age who lived in Zola North West township, Soweto, Johannesburg. They were mainly Zulu. Examinations were made at Mofolo Clinic. These people, like the elderly group at Phokeng, have been investigated in the course of a number of other research projects.

\section{Caucasians}

(1) Adult males employed in the gold-mining industry are examined annually at the Miners Medical Bureau of the Chamber of Mines of South Africa, Johannesburg. X-rays of such persons were randomly selected. Groups were aged 18-20, 25-34, 35-44, and 55-64 years, and included fifty or more persons in each age group. They may be regarded as fairly representative of the general male population.

(2) A second group included males and females $X$-rayed at the General Hospital, Johannesburg. In each age group, 18-20, 25-34, 35-44, 55-64 years, there were at least fifty or more persons. Plates of persons X-rayed specifically for enlargement of heart were excluded. Data obviously are less representative than those on the mine workers.

Although it transpired that the information on these groups of Caucasians was satisfactory for the purpose in mind, they were cetainly not as random as was desired. Yet attempts to secure chest X-rays of truly random groups from the local community had to be abandoned, due to the high rate of refusals.

\section{Methods}

$X$-rays. Exposures (posterior-anterior) were made at a standard distance of $6 \mathrm{ft}$, at full inspiration. Plates were checked to ensure that the latter prevailed. A variable proportion, approaching $10 \%$ in some groups, had to be discarded.

Measurement of heart diameter. The transverse diameter of the heart was obtained from the sum of the maximum projections of the right and left borders from the mid-line. X-ray plates were placed on a standard viewing box; after marking positions with a fine pencil, measurements were made using a transparent scale, graduated in millimetres.

Measurement of thoracic diameter. It is unfortunate that different methods are being used. (1) In the Jamaican study, Ashcroft \& Miall (1969) measured the maximum diameter of the thoracic cavity at full inspiration. (2) In the Tecumseh investigation, Oberman et al. (1967) measured the transverse diameter of the thorax at the level of the dome of the right diaphragm at full inspiration.

We measured thoracic diameter by both methods. In our series, mean diameter, measured as at Tecumseh, was shorter by $2.1 \%$ (young people) to $3.9 \%$ (old people) than the corresponding means measured as in Jamaica. Moreover, mean cardio-thoracic 
ratio, as measured at Tecumseh, was lower by the same proportions compared with the means as measured in Jamaica. Obviously, the different methods of measuring result in marked differences in the proportions of subjects having ratios of 0.55 or more; i.e. frequency of cardiomegaly essentially is lower when measured as at Tecumseh. All measurements were made by two persons. Mean differences between observers, in a series of fifty X-ray plates, for heart and thoracic diameters were 0.8 and $0.9 \%$, respectively.

\section{Additional studies}

In the elderly Negro populations at Phokeng and Zola, studies were made, inter alia, of height, weight and blood pressure. Height and weight: Height was measured with shoes removed. Weight was recorded likewise. Blood pressure: Measurements were made with a mercury sphygmomanometer, with subjects in the sitting position, according to directions given in a WHO Expert Committee Report (1959). When measuring diastolic pressure, the end-point was taken as the time of disappearance of sound.

\section{Results}

Information on height, weight and blood pressure in certain of the elderly Negro groups is given in Table 1.

All cardio-thoracic data secured are not given; data on the age groups $25-34,35-44$, and 55-64 years, were deemed sufficient to permit the drawing of conclusions, and are given in Tables 2-4. For
TABLE 1. Height, weight, and blood pressure data on Southern African Negroes, 55-64 years (means and standard ? deviations)

\begin{tabular}{|c|c|c|c|c|c|}
\hline & \multirow[b]{2}{*}{$\begin{array}{c}\text { No. } \\
\text { subjects }\end{array}$} & \multirow[b]{2}{*}{$\begin{array}{l}\text { Height } \\
\text { (cm) }\end{array}$} & \multirow[b]{2}{*}{$\begin{array}{c}\text { Weight } \\
\text { (kg) }\end{array}$} & \multicolumn{2}{|c|}{ Blood pressure } \\
\hline & & & & $\begin{array}{l}\text { Diastolic } \\
(\mathrm{mmHg})\end{array}$ & $\begin{array}{c}\text { Systolic } \\
(\mathrm{mmHg})\end{array}$ \\
\hline \multicolumn{6}{|l|}{ Rural } \\
\hline $\begin{array}{l}\text { Mean } \\
\text { SD }\end{array}$ & 19 & $\begin{array}{r}168.4 \\
6.8\end{array}$ & $\begin{array}{r}56 \cdot 9 \\
8.8\end{array}$ & $\begin{array}{l}80 \\
13\end{array}$ & $\begin{array}{r}127 \\
29\end{array}$ \\
\hline $\begin{array}{c}\text { Females } \\
\text { Mean } \\
\text { SD }\end{array}$ & 29 & $\begin{array}{r}156.9 \\
5.4\end{array}$ & $\begin{array}{l}60 \cdot 0 \\
12 \cdot 1\end{array}$ & $\begin{array}{l}83 \\
15\end{array}$ & $\begin{array}{r}133 \\
32\end{array}$ \\
\hline $\begin{array}{l}\text { Urban } \\
\text { Males }\end{array}$ & & & & & \\
\hline $\begin{array}{l}\text { Mean } \\
\text { SD }\end{array}$ & 45 & $\begin{array}{r}169 \cdot 7 \\
7.2\end{array}$ & $\begin{array}{l}64 \cdot 4 \\
12 \cdot 3\end{array}$ & $\begin{array}{l}84 \\
14\end{array}$ & $\begin{array}{r}135 \\
31\end{array}$ \\
\hline $\begin{array}{c}\text { Females } \\
\text { Mean } \\
\text { SD }\end{array}$ & 52 & $\begin{array}{r}157 \cdot 4 \\
5 \cdot 8\end{array}$ & $\begin{array}{l}68 \cdot 8 \\
12 \cdot 4\end{array}$ & $\begin{array}{l}86 \\
16\end{array}$ & $\begin{array}{r}140 \\
34\end{array}$ \\
\hline
\end{tabular}

comparison, mean cardio-thoracic ratios are given for the two Jamaican populations, also for the Caucasian groups studied in Wales and at Tecumseh. The comparative figures given for Tecumseh are approximate for the following reasons:

(1) Data on the 'normal' and 'abnormal' groups were combined proportionally to yield a random group. This was considered legitimate since dif ferences in mean ratio between the 'normal' and 'abnormal' groups were not large; some differences were not significant, others only at the $5 \%$ level.

TABLE 2. Cardio-thoracic data on population groups of 25-34 years (means and standard deviations)

\begin{tabular}{|c|c|c|c|c|c|c|c|c|c|c|}
\hline & \multicolumn{5}{|c|}{ Males } & \multicolumn{5}{|c|}{ Females } \\
\hline & No. & $\begin{array}{l}\text { Heart } \\
\text { diam. } \\
(\mathrm{cm})\end{array}$ & $\begin{array}{l}\text { Thoracic } \\
\text { diam. } \\
\text { (cm) }\end{array}$ & $\mathrm{C} / \mathrm{T}$ & $\% 0.55+$ & No. & $\begin{array}{l}\text { Heart } \\
\text { diam. } \\
(\mathrm{cm})\end{array}$ & $\begin{array}{l}\text { Thoracic } \\
\text { diam. } \\
(\mathrm{cm})\end{array}$ & $\mathrm{C} / \mathrm{T}$ & $\% 0.55+$ \\
\hline $\begin{array}{l}\text { Negro } \\
\text { Rural: }\end{array}$ & & & & & & & & & & \\
\hline $\begin{array}{l}\text { Saulspoort } \\
\text { SD }\end{array}$ & 58 & $\begin{array}{r}12 \cdot 5 \\
1 \cdot 4\end{array}$ & $\begin{array}{r}28 \cdot 0 \\
1 \cdot 7\end{array}$ & $\begin{array}{l}0.45 \\
0.04\end{array}$ & $2 \cdot 9$ & 61 & $\begin{array}{r}11 \cdot 7 \\
1 \cdot 3\end{array}$ & $\begin{array}{r}25 \cdot 2 \\
1 \cdot 5\end{array}$ & $\begin{array}{l}0.47 \\
0.05\end{array}$ & $1 \cdot 6$ \\
\hline $\begin{array}{l}\text { Urban } \\
\text { Mofolo } \\
\text { SD }\end{array}$ & 129 & $\begin{array}{r}12 \cdot 7 \\
1 \cdot 5\end{array}$ & $\begin{array}{r}28 \cdot 6 \\
1 \cdot 7\end{array}$ & $\begin{array}{l}0.44 \\
0.04\end{array}$ & $1 \cdot 5$ & 146 & $\begin{array}{r}12 \cdot 1 \\
1 \cdot 2\end{array}$ & $\begin{array}{r}26 \cdot 3 \\
1 \cdot 4\end{array}$ & $\begin{array}{l}0.46 \\
0.04\end{array}$ & 0.6 \\
\hline $\begin{array}{l}\text { Rural } \\
\text { Malawi } \\
\text { SD }\end{array}$ & 56 & $\begin{array}{r}13 \cdot 6 \\
1 \cdot 4\end{array}$ & $\begin{array}{r}28 \cdot 0 \\
1.6\end{array}$ & $\begin{array}{l}0.48 \\
0.05\end{array}$ & $7 \cdot 1$ & & & & & \\
\hline $\begin{array}{l}\text { Rural } \\
\text { Mozambique } \\
\text { SD }\end{array}$ & 54 & $\begin{array}{r}13.9 \\
1.4\end{array}$ & $\begin{array}{r}28 \cdot 4 \\
1 \cdot 7\end{array}$ & $\begin{array}{l}0.49 \\
0.05\end{array}$ & $2 \cdot 4$ & & & & & \\
\hline $\begin{array}{l}\text { Caucasian } \\
\text { Hospital } \\
\text { SD }\end{array}$ & 56 & $\begin{array}{r}13 \cdot 1 \\
1 \cdot 4\end{array}$ & $\begin{array}{r}30 \cdot 1 \\
1 \cdot 8\end{array}$ & $\begin{array}{l}0.43 \\
0.05\end{array}$ & $3 \cdot 6$ & 42 & $\begin{array}{r}11.9 \\
1.4\end{array}$ & $\begin{array}{r}27 \cdot 4 \\
1 \cdot 5\end{array}$ & $\begin{array}{l}0.44 \\
0.04\end{array}$ & 0 \\
\hline $\begin{array}{l}\text { Miners } \\
\text { SD }\end{array}$ & 56 & $\begin{array}{r}13 \cdot 3 \\
1 \cdot 4\end{array}$ & $\begin{array}{r}30 \cdot 7 \\
1 \cdot 7\end{array}$ & $\begin{array}{l}0.43 \\
0.04\end{array}$ & 0 & & & & & \\
\hline Tecumseh & $*$ & $13 \cdot 4$ & $31 \cdot 1$ & 0.43 & & & $11 \cdot 8$ & $26 \cdot 7$ & 0.44 & \\
\hline
\end{tabular}

* Numbers of subjects cannot be inserted since data were obtained by extrapolation. 
TABLE 3. Cardio-thoracic data on population groups of 35-44 years (means and standard deviations)

\begin{tabular}{|c|c|c|c|c|c|c|c|c|c|c|}
\hline & \multicolumn{5}{|c|}{ Males } & \multicolumn{5}{|c|}{ Females } \\
\hline & No. & $\begin{array}{l}\text { Heart } \\
\text { diam. } \\
(\mathrm{cm})\end{array}$ & $\begin{array}{l}\text { Thoracic } \\
\text { diam. } \\
\text { (cm) }\end{array}$ & $\mathrm{C} / \mathrm{T}$ & $\% 0.55+$ & No. & $\begin{array}{c}\text { Heart } \\
\text { diam. } \\
(\mathrm{cm})\end{array}$ & $\begin{array}{l}\text { Thoracic } \\
\text { diam. } \\
\text { (cm) }\end{array}$ & $\mathbf{C} / \mathbf{T}$ & $\% 0.55+$ \\
\hline $\begin{array}{l}\text { Negro } \\
\text { Rural }\end{array}$ & & & & & & & & & & \\
\hline $\begin{array}{l}\text { Saulspoort } \\
\text { SD }\end{array}$ & 55 & $\begin{array}{r}12 \cdot 8 \\
1.6\end{array}$ & $\begin{array}{r}28 \cdot 9 \\
1.7\end{array}$ & $\begin{array}{l}0.45 \\
0.04\end{array}$ & $5 \cdot 5$ & 60 & $\begin{array}{r}12 \cdot 0 \\
1 \cdot 2\end{array}$ & $\begin{array}{r}253 \\
1.6\end{array}$ & $\begin{array}{l}0.47 \\
0.04\end{array}$ & $1 \cdot 7$ \\
\hline Urban & & & & & & & & & & \\
\hline $\begin{array}{l}\text { Mofolo } \\
\text { SD }\end{array}$ & 134 & $\begin{array}{r}12 \cdot 9 \\
1.5\end{array}$ & $\begin{array}{r}28 \cdot 9 \\
1.8\end{array}$ & $\begin{array}{l}0.45 \\
0.04\end{array}$ & $2 \cdot 9$ & 113 & $\begin{array}{r}12 \cdot 5 \\
1 \cdot 2\end{array}$ & $\begin{array}{r}26 \cdot 6 \\
1 \cdot 5\end{array}$ & $\begin{array}{l}0.47 \\
0.04\end{array}$ & $1 \cdot 8$ \\
\hline $\begin{array}{l}\text { Rural } \\
\text { Malawi } \\
\text { SD }\end{array}$ & 58 & $\begin{array}{r}13.9 \\
1.6\end{array}$ & $\begin{array}{r}28 \cdot 5 \\
1 \cdot 7\end{array}$ & $\begin{array}{l}0.49 \\
0.05\end{array}$ & 6.9 & & & & & \\
\hline $\begin{array}{l}\text { Rural } \\
\text { Mozambique } \\
\text { SD }\end{array}$ & 61 & $\begin{array}{r}14 \cdot 1 \\
1.6\end{array}$ & $\begin{array}{r}28 \cdot 7 \\
1 \cdot 8\end{array}$ & $\begin{array}{l}0.49 \\
0.04\end{array}$ & $10 \cdot 0$ & & & & & \\
\hline $\begin{array}{l}\text { Rural } \\
\text { Jamaican } \\
\text { SD }\end{array}$ & 68 & $\begin{array}{r}13 \cdot 6 \\
1.5\end{array}$ & $\begin{array}{r}28 \cdot 4 \\
1.7\end{array}$ & $\begin{array}{l}0.48 \\
0.04\end{array}$ & $7 \cdot 1$ & 63 & $\begin{array}{c}12 \cdot 7 \\
1 \cdot 1\end{array}$ & $\begin{array}{r}25.8 \\
1.6\end{array}$ & $\begin{array}{l}0.49 \\
0.04\end{array}$ & $8 \cdot 6$ \\
\hline $\begin{array}{l}\text { Urban } \\
\text { Jamaican } \\
\text { SD }\end{array}$ & 89 & $\begin{array}{r}13 \cdot 5 \\
1 \cdot 3\end{array}$ & $\begin{array}{r}28 \cdot 9 \\
1.5\end{array}$ & $\begin{array}{l}0.47 \\
0.04\end{array}$ & $2 \cdot 2$ & 118 & $\begin{array}{r}13 \cdot 0 \\
1 \cdot 3\end{array}$ & $\begin{array}{r}26 \cdot 0 \\
1.6\end{array}$ & $\begin{array}{l}0.50 \\
0.04\end{array}$ & $13 \cdot 0$ \\
\hline $\begin{array}{l}\text { Caucasian } \\
\text { Hospital } \\
\text { SD }\end{array}$ & 51 & $\begin{array}{r}13.6 \\
1.6\end{array}$ & $\begin{array}{r}30 \cdot 4 \\
1.6\end{array}$ & $\begin{array}{l}0.45 \\
0.05\end{array}$ & $7 \cdot 8$ & 49 & $\begin{array}{r}12 \cdot 5 \\
1 \cdot 3\end{array}$ & $\begin{array}{r}27 \cdot 7 \\
1.6\end{array}$ & $\begin{array}{l}0.45 \\
0.05\end{array}$ & 0 \\
\hline $\begin{array}{l}\text { Miners } \\
\text { SD }\end{array}$ & 58 & $\begin{array}{r}13 \cdot 8 \\
1.5\end{array}$ & $\begin{array}{r}31.6 \\
1.7\end{array}$ & $\begin{array}{l}0.44 \\
0.04\end{array}$ & 0 & & & & & \\
\hline $\begin{array}{l}\text { Wales } \\
\text { SD }\end{array}$ & 98 & $\begin{array}{r}13.9 \\
1.4\end{array}$ & $\begin{array}{r}31.4 \\
1.8\end{array}$ & $\begin{array}{l}0.44 \\
0.04\end{array}$ & $1 \cdot 0$ & 99 & $\begin{array}{r}12 \cdot 7 \\
1 \cdot 1\end{array}$ & $\begin{array}{r}27.9 \\
1.7\end{array}$ & $\begin{array}{l}0.45 \\
0.03\end{array}$ & 0 \\
\hline Tecumseh & * & 13.9 & $31 \cdot 6$ & 0.44 & & & $12 \cdot 3$ & $26 \cdot 6$ & 0.46 & \\
\hline
\end{tabular}

* Numbers of subjects cannot be inserted since data were obtained by extrapolation.

(2) Data were extrapolated from age groups, $20-29,30-39,40-49,50-59,60-69$ years, to age groups $25-34,35-44$, and $55-64$ years.

(3) The data at Tecumseh were further re-calculated to compare fairly with data from Jamaica and Wales, i.e. mean thoracic diameter in the Tecumseh data was increased, and mean cardio-thoracic ratio decreased, by the appropriate percentages given above.

\section{Comments on results}

(1) For Caucasian male groups-in South Africa, Wales and Tecumseh-there were no significant differences in mean cardio-thoracic ratio. The same applied to the female Caucasian groups. Hence, it is judged that the techniques and measurements pursued locally were satisfactory.

(2) For the South African Negro males, cardiothoracic data did not differ significantly from corresponding data on the Caucasian male groups. In respect of females, mean values on local Negroes, apart from those in the 55-64 year period, were greater $(P<0.05)$ than the highest of means in the Caucasian groups. In the South African Negro groups, a rural-urban differential was not apparent.
(3) Mean data on South African Negro groups were significantly lower $(P<0.01)$ than those on the Jamaican Negro groups. Differences were already apparent in the young. Differences between the two populations appeared to increase with age, and were more marked in females than males.

(4) In strong contrast to the foregoing, the Negro groups of males from Malawi and Mozambique had cardio-thoracic ratios significantly greater $(P<0.01)$ than those on the South African Negro groups. Data on Negro males from these two territories, were also greater, although not significantly, than the data given for the Jamaican Negro males. Data on Malawi males of 18-20 years (not given in Tables) corresponded with data on Caucasian males of 55-64 years.

(5) In the respective sexes, of those with cardiothoracic ratios of 0.55 or more, for each sex-age period, the proportions among the Caucasians, local and overseas, also among the South African Negroes, were of the same order. In the 55-64 year age group, proportions were lower than those obtaining with the Jamaican groups. In the 35-44 year age group, this prevailed only in groups of females.

(6) Although detailed data are not given, there 
TABLE 4. Cardio-thoracic data on population groups of 55-64 years (means and standard deviations)

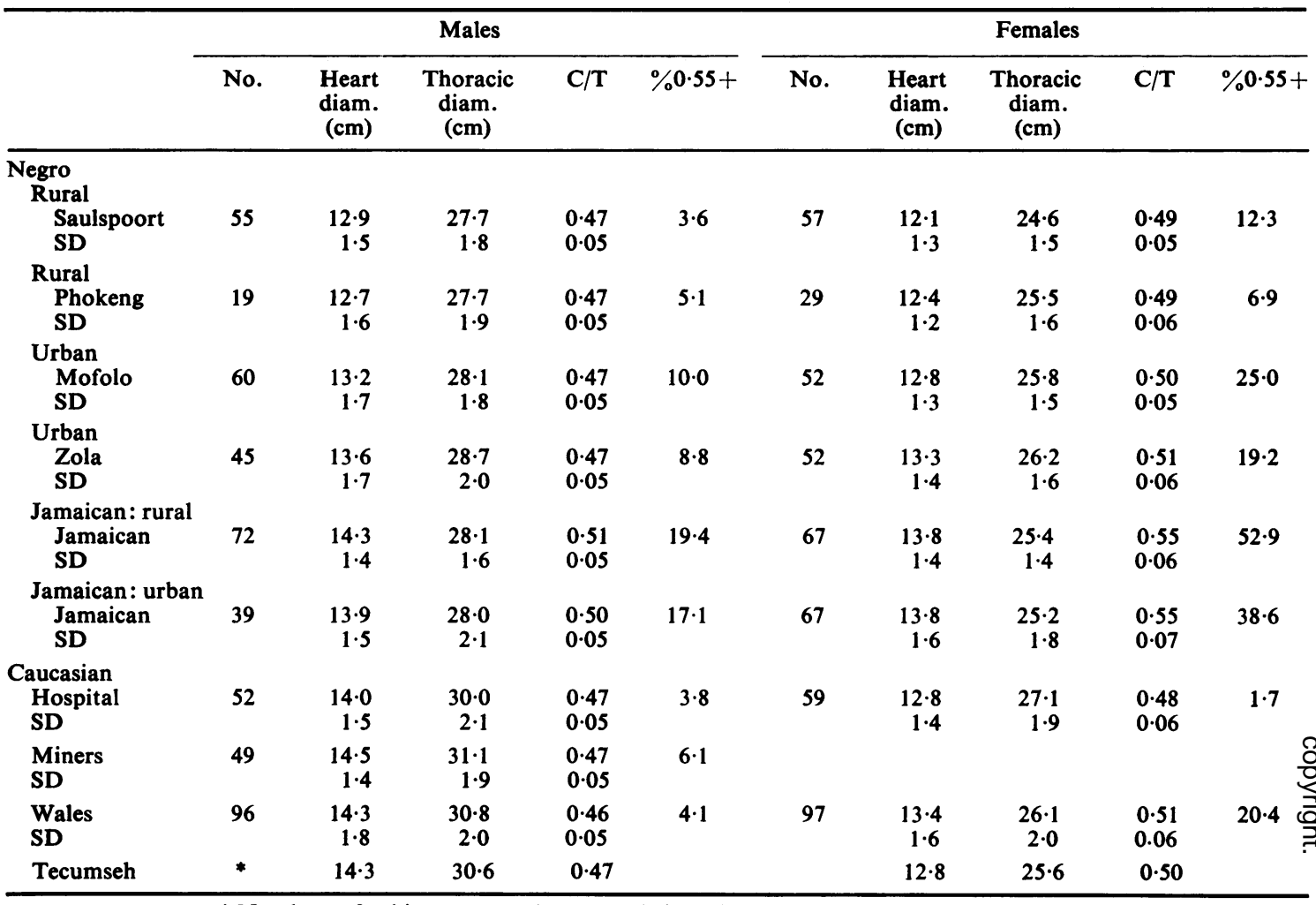

* Numbers of subjects cannot be inserted since data were obtained by extrapolation.

were wide ranges of cardio-thoracic ratio found in all groups. Even in the Tecumseh 'normal' population, the range for the 20-29 year group was $0.32-$ 0.56 in males, and $0.32-0.53$ in females. In the age group $70+$ years, corresponding ranges were 0.34 0.52 and $0.40-0.64$, respectively (original, not recalculated, data).

(7) In the elderly South African Negro groups, cardio-thoracic ratio, apart from increasing with age, was influenced by weight and blood pressure. Weight : The ratio increased with weight, although, as with Jamaicans, the correlation coefficients in the elderly groups were found to be not significant at the $5 \%$ level. Blood pressure: The ratio increased with rise in systolic and diastolic pressures, as was observed in the Jamaican and Welsh groups: however, the correlation coefficients in respect of diastolic pressure were not significant with elderly males, and barely with females. Elderly rural South African Negro males and females had mean weights lower than those of urban Negroes, and lower than those of elderly Caucasians. The same differential, with limitations, prevailed with blood pressure. Previously, numerous anthropometric, blood pressure, and other studies have been pursued on young adults of 18-20 years in many local tribes of Negroes, including Shangaans in Mozambique; despite some dissimilarities, data for height and weight almost invariably were significantly lower in these people than in corresponding Caucasian groups (Walker, 1966).

(8) In all the Negro groups studied, in Southern Africa and Jamaica, there was relative constancy of thoracic diameter. Between Negroes in Malawi, Mozambique, and Jamaica, on the one hand, and the South African Negro groups on the other, the difference lies in the heart diameter.

\section{Discussion}

Gelfand (1952), in Rhodesia, observed a form of enlargement of the heart (radiographic appearance) in young Negroes 'who at the same time appear physically well'. In Uganda, Brown (1953) noted that in young Negroes (Baganda), 'The heart tends to be centrally situated, it is often globular in shape, its conus may be prominent, its breadth is frequently greater than half the chest width, and, in the lateral view, its lie is sometimes seen to be more horizontal than in the European.' The pattern thus described in young men and women was well illustrated. The 
same phenomenon was noted by Pellegrina et al. (1953) in young males in French West Africa. In South Africa, in Pretoria, Oosthuizen (1958) also pointed out that in groups of local Negroes 'the cardiac silhouette is more transverse in position, creating the erroneous impression that the heart, as shown by the transverse diameter, is larger than in the European.' In none of these investigations were precise details given of heart and chest size, nor prevalence of the condition in sex-age groups. In the regions mentioned, necropsy studies on young people revealed no evidence of enlargement of heart. The finding of high cardio-thoracic ratios in Jamaican Negroes should have been not unexpected; lack of reports bearing on the situation in U.S.A. Negroes is puzzling.

From the present investigations, all that is claimed is that the ratios in the particular South African Negro groups studied are much the same as those of the Caucasians; yet ratios in both these populations are significantly lower $(P<0.01)$ than the data on the groups of Malawi and Mozambique Negro males, also the Jamaican groups.

Clearly, the phenomenon is not explicable on the basis of differences in weight or in prevalences of hypertension. The fact that the phenomenon is apparent in the young strongly supports the view of Ashcroft \& Miall (1969) that an ethnic difference is responsible. Since the phenomenon is absent in some but present in other Negro groups, endeavours should be made in all African territories to determine whether cardiomegaly of ethnic origin is a feature of the indigenous inhabitants. This may readily be ascertained by making chest X-rays of relatively small numbers of young adults of both sexes.

The finding of almost the same mean cardiothoracic ratio in South African Negroes compared with Caucasians is interesting in view of the reported commonness of idiopathic cardiomyopathy in the Negroes. A high ratio is a prominent feature of cardiomyopathy, and is present even when the disease is first detected (Gottsman et al., 1971). In South Africa it has been stated that this disease is responsible for more admissions of Negroes to hospital than any other cardio-vascular disease (Schwartz, Schamroth \& Seftel, 1958; Snyman, 1962; Schire, 1964, 1971). At Baragwanath Hospital (2300 beds), Johannesburg, there are usually eight to twelve patients with cardiomyopathy in the wards at any one time (Schmaman, 1971). However, since the Negro population at risk is about 750,000 , of whom about 60,000 are 50 or more years, it may be inferred that the prevalence of the disease in the middle aged and elderly is too infrequent to have a significant bearing on the mean data presented in this paper.

\section{Acknowledgments}

For facilitating the taking of the X-ray plates, also for permitting use of material available, we are very grateful to the following-Dr F. P. Jooste, Rustenburg Hospital, Dr G. H. Roux, George Stegmann Mission Hospital, Dr G. E. Mearns, Rustenburg Platinum Mines Hospital, Dr B. R. Richards and Mrs J. Richards, City Health Department, Johannesburg, and Dr G. K. Sluis-Cremer and Dr F. J. Wiles, Miners Medical Bureau, Johannesburg. For advice and other help, we are indebted to Dr A. Solomon, Chief Radiologist, Baragwanath Hospital, Johannesburg. Miss M. J. Fick assisted with some of the measurements.

\section{References}

Ashcroft, M.T. \& Miall, W.E. (1969) Cardio-thoracic ratios in two Jamaican communities. American Journal of Epidemiology, 89, 161.

Brown, J.S. (1953) Some features of Ganda X-ray anatomy. East African Medical Journal, 30, 144.

Cochrane, A.L., Miall, W.E. \& Clarke, W.G. (1956) Results of a chest X-ray survey in the Vale of Glamorgan. Tubercle, London, 37, 417.

GelfaND, M. (1952) Recent advances in tropical medicine. No. 3. Cardiac and vascular disorders in the African. West African Medical Journal, 1, 91.

GotSMAN, M.S., vaN DER HoRST, R.L., WINSHIP, W.S. \& SCHAEFER, T.G. (1971) Heart size in primary myocardial disease. South African Medical Journal, 45, 744.

Oberman, A., Myers, A.R., Karunas, T.M. \& Epstein, H.E. (1967) Heart size of adults in a natural populationTechumseh, Michigan: variation by sex, age, height, and weight. Circulation, 35, 724.

Oosthuizen, S.F. (1958) Certain differences in the radiological appearance between the lung fields of the African and the European. Medical Proceedings, 4, 635.

Pellegrino, A., Favre, R. \& Douerin, P. (1955) Réflexion sur l'aspect radiologique normal du coeur de l'Africain. Bulletin Medical de l'Afrique Occidentale Française, 12, 111.

SCHRIRE, V. (1964) Racial incidence of hypertension, rheumatic, and syphylitic disease of the heart at Groot Schuur Hospital, Cape Town, during the 10-year period: 1952-61 . South African Medical Journal, 38, 488.

SCHRIRE, V. (1971) Heart disease in Southern Africa. South African Medical Journal, 45, 634.

Schwartz, M.B., Schamroth, L. \& Seftel, H.C. (1958) The pattern of heart disease in the urbanized (Johannesburg) African. Medical Proceedings, 4, 275.

Schmaman, A. (1971) Personal communication.

SNYMAN, H.W. (1962) The pattern of heart disease in Africa. Medical Proceedings, 8, 391.

Trowell, H.C. (1960) Non-Infective Disease in Africa, p. 75. Arnold, London.

WALKER, A.R.P. (1966) Nutritional, biochemical, and other studies on South African populations. South African Medical Journal, 40, 814.

WALKeR, A.R.P., WALKer, B.F. \& RichaRdSON, B.D. (1971) Metacarpal bone dimensions in young and aged South African Bantu consuming a diet low in calcium. Postgraduate Medical Journal, 47, 320.

WHO EXPERT COMMITTEE RePORT (1959) Hypertension and coronary heart disease. Classification and criteria for epidemiological studies. WHO Technical Report Series. No. 168 , Geneva. 